\title{
Fostering capacity building on Scenarios and Modelling on Biodiversity and Ecosystem Services to Support Human Well-Being
}

\author{
Carlos A. Joly ${ }^{1 *(\mathbb{D}, \text { Paula Drummond de Castro }}{ }^{2}$ \& Simone A. Vieira ${ }^{3}$ \\ ${ }^{1}$ Universidade Estadual de Campinas, Instituto de Biologia, Departamento de Biologia Vegetal, Campinas, SP, Brasil. \\ ${ }^{2}$ Universidade Estadual de Campinas, Laboratório de Estudos Avançados em Jornalismo Científico, Campinas, SP, Brasil. \\ ${ }^{3}$ Universidade Estadual de Campinas, Núcleo de Estudos e Pesquisas Ambientais - NEPAM, Campinas, SP, Brasil. \\ *Corresponding author: Carlos A.Joly,e-mail: cjoly@unicamp.br
}

\begin{abstract}
JOLY, C.A., CASTRO, P.D., VIEIRA, S.A. Fostering capacity building on Scenarios and Modelling on Biodiversity and Ecosystem Services to Support Human Well-Being. Biota Neotropica 20(suppl.1): e20200401. https://doi.org/10.1590/1676-0611-BN-2020-04-01
\end{abstract}

Predictive models have become important tools for examining the way that systems are likely to react to environmental and policy changes while exploring uncertainties. Even considering the limits of their predictability (mostly because of data availability, and incapacity of anticipating unforeseeable events), foresight approaches became a very useful tool to increase the knowledge, engage stakeholders and create anticipatory intelligence. Therefore, they are increasingly being used to study the possible effects of human actions on Earth, its biodiversity and associated ecosystem services. Such models are typically based on a set of assumptions, so-called scenarios, which provide an approach for exploring how plausible alternative futures may unfold and comparing the potential consequences of different decisions in different future contexts.

Scenarios and models allow the exploration and communication of the results of different narratives ("futures") for social, economic and environmental development. Scenarios are indispensable for supporting science-based policy formulation and implementation (Pereira et al, 2010).

In order to capture the consequences of the growing threats to biodiversity and ecosystem services, scenarios have become timely a key component in decision-making (IPBES 2016a). There are various advantages in adopting this approach, such as: 1) the capacity to foresee future changes in biodiversity and ecosystem services as a result of fluctuations in various ecological and socioeconomic drivers, and 2) the usability at multiple spatial scales - from local to global levels which allows to understand, for example, impacts of climate change on forests and protected areas, or on management of fishing grounds. There are, however, certain constrains to this approach, for instance, the limited coverage and range of sectors and cases, and the availability of data. This shed light on a very wide range of enhancements that can be made in scenarios that would improve their use in decision-making.

The need for a step change in the capacity to foresee credible future changes was lead the Intergovernmental Platform on Biodiversity and Ecosystem Services (IPBES) that organized a working group with over 80 experts from all regions of the world, to produce a report. The Methodological Assessment report on scenarios and models of biodiversity and ecosystem services, published in 2016, become a milestone as it reviewed the state-of-the-art and highlighted the existing gaps in scenarios and models for biodiversity and ecosystem services change.
One of the key messages of the report points out that an appropriate planning, investment and capacity-building, among other efforts, could overcome significant remaining challenges in developing and applying scenarios and models (IPBES 2016b).

In this respect, and aligning with the ambition of organizations such as IPBES, the São Paulo School of Advanced Science on Scenarios and Modelling on Biodiversity and Ecosystem Services to Support Human Well-Being Scenarios (SPSAS Scenarios) addressed the relationship of dependence, particularly between ecosystem services sustained by biodiversity, and human well-being. Human well-being depends directly on ecosystem services (Pascual et al 2017) such as pollination associated with food production, protection of water resources associated with water for consumption and for energy production, mitigation of climate change impacts and intangible services fundamental to emotional and often spiritual balance. Scenarios and models that are able to capture these dependencies can become essential tools for sustainable management and development in the long-term.

Decision makers in governments, private sector and civil society want more robust information regarding plausible futures of biodiversity and ecosystem services. They want to understand how the drivers impacting biodiversity and ecosystem services might evolve in the future, and what the consequences might be for biodiversity, ecosystem services and nature's contributions to people. They also want to understand the implications of different policy choices on biodiversity and ecosystem services, and how to achieve policy targets (IPBES 2016b)

The idea was that by providing expert advice on models and scenarios that are currently available, and by explaining how to use them and in what context, the SPSAS Scenarios would make it possible to enhance the use of these tools in biodiversity and ecosystem services governance. Aiming to spread the knowledge assembled by IPBES in its assessment, and to help the biodiversity community to make a step change in its capacity to foresee plausible future changes as a result of various socioeconomic drivers, the BIOTA/FAPESP Research Program, the Brazilian Platform on Biodiversity and Ecosystem Services/BPBES and the Inter-American Institute for Global Change Research/IAI organized the São Paulo School of Advanced Science on Scenarios and Modelling on Biodiversity and Ecosystem Services to Support Human Well-Being Scenarios (SPSAS Scenarios). 
In this context SPSAS Scenarios contributed to the training of students, future researchers and professionals in the area of biodiversity and ecosystem services modelling and scenarios, who will eventually become leading academics in research centres, government agencies, companies and industries, international organizations and several other sectors and institutions.

By bringing together the team of experts that led the IPBES Methodological Assessment (IPBES 2016a, b), it was possible also to update all SPSAS Scenarios with the vision and concept of the Nature Futures Framework (Lundquist et al. 2017, Pereira et al. in press) that integrates both qualitative narratives and quantitative model output (Figure 1).

"The Nature Futures Framework (NFF) forms the foundation for developing scenarios of positive futures for nature, to help inform assessments of policy options across multiple scales. The NFF places relationships between people and nature at its core. Because people relate to nature in multiple ways, there are a wide variety of desirable nature futures, with different goals and visions which can be synergistic or in conflict with one another" (https://ipbes.net/scenarios-models).

The nine papers presented in this Special Issue of Biota Neotropica are the result of the work developed by the 90 participants of the SPSAS
Scenarios - 46 Brazilian, 23 from Latin America Countries, 9 from Europe, 6 from North America, 4 Africa and 2 from Asia/Oceania.

Each group chose a topic related to environmental change and during the school worked on incorporating layers of complexity, as the theoretical background was being presented and discussed by several experts. So, this Special Issue is the result of a collective effort on disseminating IPBES principles, tools and methodologies to train professionals to use the best available knowledge to bridge the gap between science and police, generating much better polices for biodiversity and ecosystem services conservation, restauration and sustainable use.

\section{Acknowledgements}

We thank the São Paulo Research Foundation (FAPESP) for supporting the São Paulo School of Advanced Science on Scenarios and Modelling on Biodiversity and Ecosystem Services to Support Human Well-Being (SPSAS Scenarios) through the BIOTA/FAPESP Program (Process 2018/16445-5). We also express our gratitude to all professors and students who made the SPSAS Scenarios successful. Finally, the authors are grateful to Dr. Isabel Rosas for reviewing the structure and language of the final format of this Editorial.

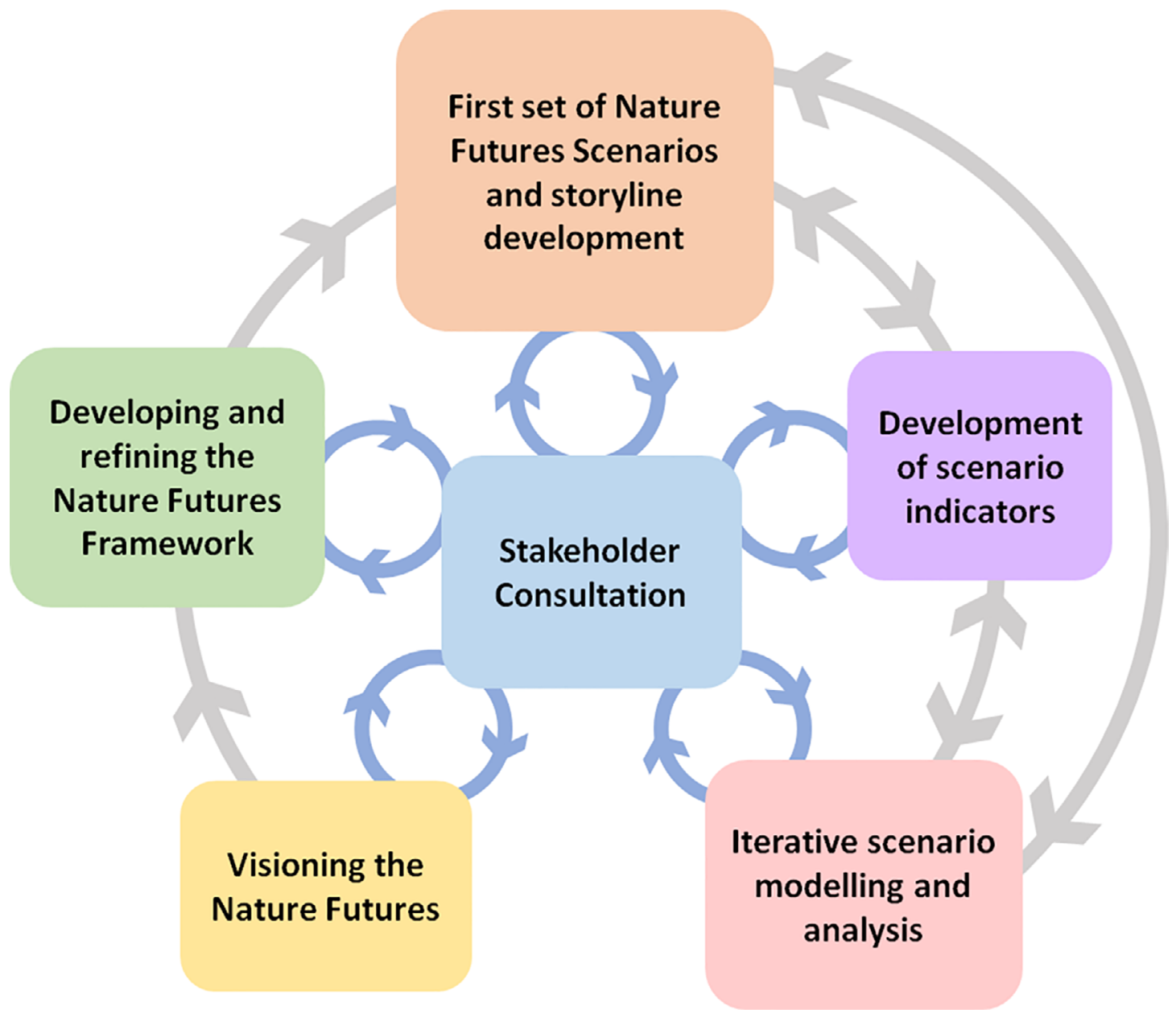

Figure 1. Iterative process for Nature Futures Scenarios development (adapted from https://ipbes.net/scenarios-models). 


\section{Author Contributions}

Carlos A. Joly, Paula Drummond de Castro and Simone A. Vieira contributed equally to manuscript preparation.

\section{Conflicts of Interest}

The authors declare that they have no conflict of interest related to the publication of this manuscript

\section{References}

IPBES 2016a. The methodological assessment report on scenarios and models of biodiversity and ecosystem services of the Intergovernmental SciencePolicy Platform on Biodiversity and Ecosystem Services. S. Ferrier, K. N. Ninan, P. Leadley, R. Alkemade, L. A. Acosta, H. R. Akçakaya, L. Brotons, W. W. L. Cheung, V. Christensen, K. A. Harhash, J. Kabubo-Mariara, C. Lundquist, M. Obersteiner, H. M. Pereira, G. Peterson,R. Pichs-Madruga, N. Ravindranath, C. Rondinini and B. A. Wintle (eds.). Secretariat of the Intergovernmental Science-Policy Platform on Biodiversity and Ecosystem Services, Bonn, Germany. 348 pages. Available at https://ipbes.net/ policy-support/assessments/methodological-assessment-scenarios-modelsbiodiversity-ecosystem

IPBES 2016b. Summary for policymakers of the methodological assessment of scenarios and models of biodiversity and ecosystem services of the Intergovernmental Science-Policy Platform on Biodiversity and Ecosystem Services. S. Ferrier, K. N. Ninan, P. Leadley, R. Alkemade, L. A. Acosta, H. R. Akçakaya, L. Brotons, W. W. L. Cheung, V. Christensen, K. A. Harhash, J. Kabubo-Mariara, C. Lundquist, M. Obersteiner, H. M. Pereira, G. Peterson,R. Pichs-Madruga, N. Ravindranath, C. Rondinini and B. A. Wintle (eds.). Secretariat of the Intergovernmental Science-Policy Platform on Biodiversity and Ecosystem Services, Bonn, Germany. 32 pages. Available at https://ipbes.net/sites/default/files/downloads/pdf/ spm_deliverable_3c_scenarios_20161124.pdf
Lundquist, C. J., Pereira, H. M., Alkemade, R., den Belder, E., Carvalho Ribeiro, S., Davies, K., Greenaway, A., Hauck, J., Karlsson-Vinkhuyzen, S., Kim, H., King, N., Lazarova, T., Pereira, L., Peterson, G., Ravera, F., van den Brink, T., Argumedo, A., Arida, C., Armenteras, D., Ausseil, A.G., Baptiste, B., Belanger, J., Bingham, K., Bowden-Kerby, A., Cao, M., Carino, J., van Damme, P.A., Devivo, R., Dickson, F., Dushimumuremyi, J.P., Ferrier, S., Flores-Díaz, A., Foley, M., Garcia Marquez, J., Giraldo-Perez, P., Greenhaigh, S., Hamilton, D.J., Hardison, P., Hicks, G., Hughey, K., KahuiMcConnell, R., Karuri-Sebina, G., De Kock, M., Leadley, P., Lemaitre, F., Maltseva, E., de Mattos Scaramuzza, C.A., Metwally, M., Nelson, W., Ngo, H., Neumann, C., Norrie, C., Perry, J., Quintana, R., Rodriguez Osuna, V.E., Roehrl, C., Seager, J., Sharpe, H., Shortland, T., Shulbaeva, P., Sumaila, U.R., Takahashi, Y., Titeux, N., Tiwari, S., Trisos, C., Ursache, A., Wheatley, A., Wilson, D., Wood, S., van Wyk, E., Yue, T.X., Zulfikar, D., Brake, M., Leigh, D., Lindgren-Streicher, P. 2017. Visions for nature and nature's contributions to people for the 21 st century, NIWA Science and Technology Series Report No. 83, NIWA, New Zealand. 123 pp. Available at https:// niwa.co.nz/sites/niwa.co.nz/files/IPBES-Nature-Futures-report 2017.pdf

Pascual U, Balvanera P, Díaz S, Pataki G, Roth E, Stenseke M, Watson RT, Başak Dessane E, Islar M, Kelemen E, et al. 2017. Valuing nature's contributions to people: the IPBES approach. Current Opinion in Environmental Sustainability 26-27:7-16. https://doi.org/10.1016/j.cosust.2016.12.006

Pereira, H.M., Leadley, P.W., Proenca, V., Alkemade, R., Scharlemann, J.P.W., Fernandez-Manjarres, J.F., Araújo, M.B., Balvanera, P., Biggs, R., Cheung, W.W.L., Chini, L., Cooper, H.D., Gilman, E.L., Guénette, S., Hurtt, G.C., Huntington, H.P., Mace, G.M., Oberdorff, T., Revenga, C., Rodrigues, P., Scholes, R.J., Sumaila, U.R. and Walpole, M., 2010.Scenarios for Global Biodiversity in the $21^{\text {st }}$ Century. Science, 330(6010): 1496-1501. https:// doi.org/ 10.1126/science.1196624

Pereira, L., Davies, K. K., den Belder, E., Ferrier, S., Karlsson-Vinkhuyzen, S., Kim, H., Kuiper, J. J., Okayasu, S., Palomo, M. G., Pereira, H. M., Peterson, G., Sathyapalan, J., Schoolenberg, M., Alkemade, R., Carvalho Ribeiro, S., Greenaway, A., Hauck, J., King, N., Lazarova, T., Ravera, F., Chettri, N., Cheung, W. W. L.,Hendriks, R. J. J., Kolomytsev, G., Leadley, P., Metzger, J. P., Ninan, K. N., Pichs, R., Popp, A., Rondinini, C., Rosa, I., van Vuuren, D., \& Lundquist, C. J. (in press) Developing multi-scale and integrative nature-people scenarios using the Nature Futures Framework. SocArXiv https://doi.org/10.31235/osf.io/ka69n 